\title{
VEILING AND MUSLIM WOMEN IN AFRICAN HISTORY SINCE THE OTTOMAN EMPIRE
}

\author{
Habibat Oladosu-Uthman* \\ Mutiat Titilope Oladejo**
}

\begin{abstract}
In Africa, the culture of veiling by Muslim women is profound. Several forms of textile and art feature in the use of the veil across Africa, reflecting how that garment has become culturally embedded in the region. It is true that Islam's integration with African cultures is very much alive and visible. The story of veiling became prominent in Africa under Ottoman rule and in the context of cross-cultural intergroup relations through the trans-Saharan trade routes. This paper focuses on the history of the veil as a spiritual, artistic, political, and economic factor in the identity-making of Muslim women in Africa. The historical method is adopted to interrogate the complexities associated with veiling, using photographic representations, books, and journals. Photographic representations of women's dress in the Ottoman Empire provides a way to understand how permeated African societies.
\end{abstract}

Keywords: veiling, culture, African history, Ottoman.

\section{Introduction}

In contemporary conceptions of veiling, African Muslim women utilise it for fashion and spirituality. This means that the typologies of veiling that depict Muslim women as followers of the injunctions of God also contain a social dimension (i.e. fashionable outfits). The role fashion plays in the hijab was displayed in Nigeria in 2005, when Saidat Otiti of Baytuzeenah stores organized a fashion show at Victoria Island, Lagos, to advertise her hijab stocks. At the event, the former deputy governor of Lagos state, Sinatu Ojikutu gave the following speech:

The Islamic way of dressing is neither traditional nor cultural, but an injunction from the almighty that women should dress simply and decently.... The idea of featuring outfits in these different categories is to show that you can dress the Islamic way as a career woman, schoolgirl, or housewife and still look trendy and fashionable. ${ }^{1}$ 
The above statement illustrates that while veiling remains an essential part of Muslim female identity, its historical process signifies varying dimensions and purposes. Recently, especially after the 9/11 attacks, veiling has assumed an international dimension beyond the Middle East, Africa, and any traditional understanding of its use. In the words of Van Santen:

In the European media, people from all walks of life regularly express their views concerning the negative effect they believe the veil or headscarf worn by Muslim women has on their liberal, progressive, secular, and above all enlightened society. The veil has in many respects become the symbol of fundamentalist Islam, understood in turn as synonymous with extremism or even terrorism. On the other hand, there is the view that Muslim women see the veil as part of their identity. More women are veiling, and more are ready to defend this choice. ${ }^{2}$

This position makes it important to consider the meaning and construction of veiling in African history. The Ottoman Empire is germane to this as it constituted a strong political factor that influenced Africa from the sixteenth century onwards.

This paper is concerned with the heterogeneity of veiling; where there are varying meanings and factors in its use that are yet to be acknowledged or understood. Amer articulated the fact that many Muslims rarely understand the nature of Muslims in other parts of the world. ${ }^{3}$ In Asher's reference to North Africa, it is assumed that veiling practices are universal, as it is often perceived that all Muslims dress the same way. Also, there is the assumption that black coloured veils are the most authentic, which compounds the challenges of veiling practices and cultures in other societies. In other words, it must be understood that Muslim women veil differently across continents and cultures. According to E.L. Guindi, veiling is a manifestation of many meanings that are often contested by men and women, Muslims and non-Muslims, and have changed over time. ${ }^{4}$ This article uses historical approach to analyse such changes since Islam was first introduced to Africa in the seventh century. The several typologies of veiling are often conflated in Africa and their historical underpinnings suggest its symbolic role in the identity of Islam in Africa. Invariably, it is synonymous with ideas, events, and actions.

Veiling as a subject of research in the humanities is important as Muslim men and women do not experience the impact of religious practices the same way. Nuances in the act of veiling are interwoven with cultural and religious interpretations. Veiling being the centre of analysis in this paper opens up an avenue for understanding the factors that either include or exclude African 
Muslim women. As Ayesha Imam puts it:

It has not been the case that woman-sympathetic discourses have been entirely lacking in the history of Islam after all, but that they have not been able to attain authority. ${ }^{5}$

From Ayesha Imam's observation, female Muslim issues are of little concern in public affairs. The exclusion of women from public affairs can only be accounted for over the decades, due to the patriarchal interpretation of the texts and pre-existing misogynistic tendencies within Muslim communities across the world. This is particularly important when attention is paid to how women were gradually removed from the realm of the texts' interpretation and knowledge production. Not only that, but the patriarchal interpretation of the concept of the veil also contributed to the invisibility of women in the public sphere. In this regard, there are exclusive fundamental interpretations of the concept of veiling in Africa. Lufti maintained that "formal Islamic discourse, whether medieval or modern, seeks a patriarchal ideal order that inherently oppresses women." 6 Bullock, on the other hand, argues that "some Islamic discourses may result in an oppressively patriarchal order, but other Islamic discourses do not." engage these two arguments is to acknowledge that understanding the Islamic texts requires in-depth knowledge of the contexts from which interpretation is made. In other words, sometimes, the interpreters of the phenomenon of veiling do not take into account the possibility of multiple interpretations that are contextually grounded and sometimes culturally bounded.

It is also important to state that some Muslim feminists are not in agreement about the contextual approach to interpretation, which seeks to be in line with Bullock's argument that to "understand Muslim women from their own perspective [is] cultural relativism." 8 According to Berktay, "cultural relativism becomes a banner under which oppression may be made to appear tolerable." She argues further that:

This benevolent cultural relativism on the part of the Western feminists sometimes goes so far as to extend a rationalisation of the segregation of women to accepting and condoning even veiling for the Middle Eastern 'sisters': 'Although universally perceived in the West as an oppressive custom, it (veiling) is not experienced as such by women who habitually wear it, (quoting Leila Ahmed)....

Leaving aside the strength of the argument about the social construction of experience and feelings, and about how misleading it, therefore, is to claim a special 'authenticity' for (only some among) them, one 
wonders whether Western feminists, who know perfectly well that these practices spring from the theology of the maintenance of socalled female purity, would ever accept 'veiling' for themselves- and not as an 'alternative' way of life, but as something compulsory, from which there is no possibility of opting out. ${ }^{10}$

A careful reading of the above suggests that there is no consensus among the critics of the veil adorned by Muslim women across the world about what constitutes 'oppressive practices'. In some quarters, veiling is seen as oppressive to women, ${ }^{11}$ while in others, judgement is subjected to different worldviews, including different ideological and political commitments and contexts. In other words, the implication of this is that women themselves should determine or define what they perceive as oppressive based on their individual contexts. Another reading is to see Muslim women as those who have surrendered themselves to the command of their Lord rather than submitting to the interpretations of patriarchal elements within Muslim societies. In line with Wadud, "as Muslims, we know the word 'Islam' is the most important part of how we understood who we are." She says further:

A Muslim or Muslimah is one who surrenders him/herself to Allah. We often translate this word as 'one who submits'; however, the concept is proactive, spiritually ripe and dynamic, and might be better translated as 'engaged surrender'. Engaged surrender involves an active consciousness in participation in our social lives, family lives, community lives, economic lives, and political lives, by the heart which is always open to the will of Allah, and which always gives precedent to Allah's will. The concept we have been inclined towards- submission- sometimes gives the idea that there is no will. But the one who willfully submits to the will of Allah is engaged in surrender. ${ }^{12}$

Similarly, a quick look at the "golden era" of Islam (the Abbasid period) gives a clear picture of how women were brought back to a state of being "muted" or "unheard". It was actually during this period that women were once again seen as objects of amusement and sexual gratification. According to Mernissi, ${ }^{13}$ (1996: 14), the "triumph of political/economic power of the Abbasid state was accompanied by, and founded on, the institutionalization of female slavery and subordination to men". She argues further:

From now on, this era-eulogized as the Golden Age of Islam-would provide the stuff of endless fantasy (and misogyny) to both Muslims 
and non-Muslims. The "tradition of historicizing women as active, full participants in the making of culture" would come to be replaced by a "memory in which women have no right to equality". ${ }^{14}$

Asma Barlas corroborated Mernissi in the following lines:

Indeed, over the centuries, women would be marginalized not only in memory but also in fact within states and religious communities. This is because, women were acknowledged as having the same sexual drives as men and the same right to fulfil them; moreover, women and men were seen to be equally responsible for creating (sic) a child...yet at the level of rulers and the ulama, segregation remained prevalent. ${ }^{15}$

Given the above, over the decades, the past experiences of women have served as a catalyst for women's liberation from oppressive interpretations of the texts, to become more aware of their relevance in Muslim societies, even as the veil remains the source of their identities. In Africa, beginning in the 1970s, female emancipation has been linked to the institution of veiling. This was also the case in Iran after the 1979 revolution. At the onset of the Islamic regime in Iran, according to Afsaneh:

Negative news about women's daily lives in Iran continues unabated. Seemingly trivial matters, such as the shape and colour of a woman's scarf or the thickness of her stockings, continue to be contested daily, largely among men. Women are far from legal equals of men. Despite many years of hard work by a remarkably active group of women inside and outside the Majlis (the Iranian parliament), many discriminatory laws passed within the first few months and years of the new regime remain on the books and in full force...secular feminists...often feel silenced by the dominant cultural climate. ${ }^{16}$

However, the above situation did not stop Iranian women from exerting their potential, despite the hostile climate in which they operated. Iranian women instead witnessed incredible intellectual flourishing as well as cultural production. They started making their presence visible in practically every field of artistic creation, professional achievement, educational and industrial institutions, including in sports activities. This is not to say that there were no restrictions, but Iranian women dared all consequences by jumping the fences. This is attested to by Haideh, as follows:

They (women's activities and activism in the Islamic Republic of Iran)...signify only one thing: women's determination and their 
enormous efforts to escape the prisons of the femininity and sex roles defined and guarded by the guardians of shariah. The Islamic regime has not opened the gates. Women are jumping over the fences. ${ }^{17}$

In other words, veiling can be viewed within Islamic societies as an emblem of spiritual, political, economic, as well as moral evolution, regardless of geography or affiliation. This understanding has helped Iranian women prove their creative energy against all odds. The most glaring example according to Afsaneh has been women turning to the "production and directing of films, given the restrictions at the level of acting". This is also reflected "in fields such as photography, painting, sculpture, literary production, publishing, women have established themselves on an unprecedented scale..."18

\section{Veiling Concepts and Theories}

No doubt, there is a lack of discussion about veiling in Africa. Few scholarly works have bothered to dabble with it, perhaps because of its complexity. Certainly, veiling has various meanings. Moors and Tarlo, for example, described it as fashionable dress. ${ }^{19}$ This brings to fore styles of veiling and the sense of attraction it creates. The nexus between veiling and fashion in Africa negates the assertion of Jean Allman that Africans are people without fashion. ${ }^{20}$ The typologies of veiling in Africa are such that several fashion generations have evolved over the centuries. Beyond fashion, veiling also represents national interests; the paradigms of time and social change are likewise indispensable when analysing the trajectories of veiling. Against the assertion that African Muslim women were not veiled before the 1970s, this paper argues that veiling has existed among Muslim women in Africa for over seven centuries. As evident in Renne (2013), pictorial representations of veiled African women demonstrates the different types of veiling culture adopted over the years.

Renne's book comprehensively projects the conceptual meaning of veiling adopted in this paper. From Zanzibar in East Africa to Ibadan in West Africa, veiling has assumed various forms over the years, incorporating issues of class, political power, and economy, among others. It is important to note the fact that this work takes the literal, etymological, as well as theological connotations of veiling into account. The word veil is a contested one among scholars due to the various interpretations given it. Just as "there is no practice without a theory," ${ }^{21}$ so Muslims have formed many theories about veiling practices. But one thing is still lacking: a contextual interpretation. This is necessary in order to showcase the dynamic as well as egalitarian nature of the message of the 
Qur'an. In other words, despite the fact that the message of Islam is universal, it nevertheless gives room for differences in interpretation, which are regarded as a form of blessing.

Amina Wadud, in her book, Inside the Gender Jihad, gave an expository analysis of when, how, and where a Muslim woman wears the hijab. ${ }^{22}$ The explanations indicate how fluid veiling practices are. In the words of Amer, in the context of Africa this fluidity goes thus:

Some progressive Muslims embrace veiling because they consider it a cultural practice specific to the Muslim-Majority nation to which they or their ancestors belong and which they want to maintain. This applies to many African Muslims, for whom covering their hair in some fashion is part of cultural tradition. For them, veiling represents a way of reconnecting deeply with their cultural and religious heritage, their faith and spirituality. ${ }^{23}$

The fluidity expressed here is evident, for example, in Senegal where traditional styles of clothing and veiling were religiously inspired by the transSaharan trade and remain in the nexus of tradition, spirituality, and modernity.

\section{Veiling in Africa: Historical Perspectives}

Photographic representations of veiling are manifested in the cult ure of cost umes in the Ottoman Empire. Portraits of Muslim women in imperial times show how Muslim women wore the veil. The photograph on page 190 of Nolan's work, for example, shows this; the women pose in different costumes ${ }^{24}$ and the typologies of appearances signify how veiling was an integral part of Ottoman society. The diffusion of Ottoman forms of veiling mixed with the dressing culture of the Arabs, occurred through the trans-Saharan trade and the Indian Ocean. Veil fashioning in Ottoman society was aided by the cotton industry. The imperial transfer of cotton had religious, fashion, and economic underpinnings and allowed dressing styles to expand within Africa after the eighteenth century. According to Faroqhi, the imperial interests of the Ottomans resulted in the projection of its textile economy. ${ }^{25}$ The textile industry of the Ottoman world advanced the manufacturing traditions of the wider Islamic World. The gradual Ottoman penetration of Cairo in the seventeenth century then influenced dressing cultures. ${ }^{26}$ With trade and diplomatic relations, artisans and craftsmen adopted Ottoman culture, and Ottoman textiles were adopted in everyday life. Textiles made by craftsmen were already seen on women in Cairo by the 1670s; Photographs from the 1900s show Muslim women in workplaces and factories 
with Ottoman-designed veils in separate groups according to age. ${ }^{27}$

In Algeria, in the early twentieth century, the Ottoman style of veiling was prevalent among Muslim women. For example, a colonial postcard of the early 1900s shows hyper-veiled (face covered) ${ }^{28}$ For French colonialists, such representations were uncomfortable; they used de-veiling as an instrument of colonisation under the guise of liberating women. Yet, unveiling women was also described as oppressive by at least one photographer, who said:

I photographed nearly two thousand people, mainly women, at the rate of two hundred days. In each village, the postmaster would call up the residents. It was the faces of the women that struck me most. They had no choice. They were forced to unveil and be photographed. They glammed at me from point-blank range, I was the first to witness the silent but fierce protest. ${ }^{29}$

Beyond this, the ideologies of independence and self-government transformed veiling into a subject of national interest across Africa. In the nineteenth century, specifically in West Africa, the use of the veil profoundly shaped how women appeared in public. This was reinforced by Uthman Dan Fodio's teachings, where he mandated that women should seek knowledge. He stated that:

Oh Muslim women, do not listen to the words of the misguided ones who seek to lead you astray by ordering you to obey your husbands instead of telling you to obey Allah and his messenger. They tell you that a woman's happiness lies in obeying her husband. This is no more than camouflage to make you satisfy their needs. They impose on you duties which neither Allah nor His messenger imposed on you. They make you cook, wash clothes and do other things they desire while they fail to teach you what Allah and His apostle have prescribed for you. Neither Allah nor His apostle charges you with such duties. ${ }^{30}$

Uthman Dan Fodio's teachings tally with how Muslim women have constructed use of the veil in public life, especially in the context of modernisation during the postcolonial period. This paper places emphasis on how the veil has historically been used to counter fundamentalist teachings that manifested in twentieth-century Africa. Emerson and Hartman analysed the intersection of modernisation and fundamentalism. ${ }^{31}$ In their exposition, it was explained that modernisation features as a threat to religious fundamentalism, hence the latter tends to regulate the impact of the former. In this construct, Muslim women in Africa used the veil to control both modernisation and fundamentalism. 
The veil controlled modernisation as it afforded Muslim women the ability to manage sexuality and maintain religious identity in public life. On the other hand, African Muslim women used the veil to control fundamentalism by seeking knowledge and professionalism following the lessons of Uthman Dan Fodio. This is emphasised in the Qur'an, where it is stated that:

Are those equal, those who know and those who do not know? It is those who are endued with understanding that receive admonition. (39:9)

Allah will raise up, to (suitable) ranks (and degrees), those of you who believe and who have been granted knowledge. Allah is wellacquainted with all ye do. (58:11)

There are quite a number of times in the Qur'an where acquisition of knowledge is well-celebrated and encouraged. It is important, therefore, to state that in line with Uthman Dan Fodio, knowledge here is gender blind; it is a religious duty prescribed for every Muslim. A proper understanding of this will continuously propel Muslim women to showcase their potential, even while still veiling. Veiling in the words of the Qur'an is an emblem of honour and liberation, not relegation and perpetual oppression. The Qur' an unequivocally states the following concerning the hijab:

And say to the believing women, that they should lower their gaze and guard their modesty: that they should not display their beauty and ornaments except what must ordinarily appear thereof, that they should draw their veils over their bosoms and not display their beauty. $(24: 31)$

O Prophet! Tell thy wives and daughters, and the believing women, that they should cast their outer garments over their persons (when abroad): that is most convenient, that they should be known (as such) and not molested. And Allah is oft-forgiving, Most Merciful. (33:59)

The above verses emphasise nothing except modesty and chastity. The object, in line with Yusuf Ali (explanation no. 3765), was not to restrict women's liberty but to protect them from harm and molestation. This was very relevant due to the existing conditions in Madinah when these verses were revealed. Those conditions are also true of the modern world, where women have become objects of play in the hands of men. In the contemporary world, the issue of veiling has attracted much debate. While in Muslim communities it has served as an expression of female identity, within the Western context, it is interpreted 
as a demonstration of the oppression and relegation of Muslim women despite the egalitarian and all-inclusive message of the Qur'an. To explain why this is, Asma' Barlas states as follows:

While a definition of patriarchy is fundamental to being able to establish the Quran as an antipatriarchal....text, and also for explaining issues of con/textuality... it does not address the problem of contextual legitimacy or the question of what constitutes a proper reading of a text. In fact, I am convinced that one of the primary reasons Muslims have failed to recover the Quran's antipatriarchal epistemology has to do with the fact that we have not systematically addressed this question, particularly in the light of the Quran's own recommended modes of reading it. ${ }^{32}$

In light of the above, this paper proposes that veiling should be viewed from a contextualised standpoint, to avoid what Asma refers to as both hermeneutic and theological failure. ${ }^{33}$

Over the twentieth century, the culture of veiling assumed several meanings under the influence of new social and political-economic factors. The coming of Wahabi influences changed perspectives on veiling, deviating from the African Islamic understanding of that practice. ${ }^{34}$ Invariably, the premise of veiling that evolved under the Ottoman Empire and later disappeared.

Among the upper class, women almost lost the right to participate in public affairs under strict new interpretations of the law. On the other hand, women in the lower class, who were just receivers of knowledge, had the freedom to interpret the use of the veil and rarely encountered limitations to work. Given this, few women with an Islamic education found it necessary to establish institutions foregrounding a feminine approach to public life in Muslim societies.

In addition to Wahabi ideas, the British also reinforced African patriarchy. In spite of this, states like Nigeria, Sudan, and Senegal witnessed a postcolonial emergence of Muslim women groups, such as the Federation of Muslim Women Associations in Nigeria (FOMWAN) ${ }^{35}$ and the women's branch of the Sudanese Communist Party. ${ }^{36}$ These groups or formations strategised agendas for Muslim women's rights, especially in the secular space, where issues of veiling became a subject of controversy.

Across all regions in Africa, Muslim women have struggled to be part of public affairs, including politics and governance, and have projected the veil as a symbol of fashion, spirituality, and identity. Also, the politics of ethnicity and religion (Islam versus Christianity) served to heightened the idea of the veil. 
Often perceived as part of Muslim culture, the veil appeared to be a political instrument for drawing lines between religions. However, in matters of gender relations, Muslim men have taken the veil as an instrument of moral and ideological policing with which they manage women, at the detriment of the required religious understanding that a woman needs her own societal identity.

Ultimately, the new forms of fundamentalist Islam that became prevalent from the 1970s led to the use of the veil as an instrument of appeasement to allow women's participation in public and democratic affairs. The fundamentalist believes that women's involvement in public issues is unnecessary. Consequently, Muslim women in countries like Sudan, Nigeria, Senegal, Niger, Kenya, and Tanzania adopted the veil for legitimacy and spiritual identity. ${ }^{37}$ To entrench and integrate veiling, several initiatives unfolded.

Despite the imperial influence of the Ottoman Empire and contact with the Arabs, African women have defined and maintained their veiling culture through a process of continuity and change. For example, the media portrayed it as an advantage to project hijab fashion in Egypt. It was stated in the Egyptianbased magazine Hijab Fashion that:

Many women assume that the hijab diminishes their elegance. And most veiled women believe that they cannot follow the trends of international fashion, and that they are limited by well-rehearsed styles considered to be the only modest ones that are suitable for veiling. However, these ideas are completely wrong. For many of the styles that are presented by the most famous designers can also be appropriate for women who veil, either as is or with small modifications in the way the clothes are worn. The woman who veils, just like the one who does not, can therefore find what suits her in most, if not all, fashion styles. And to prove this, we present to you here a few models created by some of the most famous designers for the Spring-Summer 2011 season. These styles correspond to the latest fashion trends that we described in the previous pages, and they are appropriate to wear with your hijab. This is so you can get inspired for your clothing this season and relish in the fact that you are "fashionable." ${ }_{38}$

The caption in the magazine read "Your Hijab as Inspired by International Fashion." This statement in March 2011, gives insight into the contemporary global trends underlying the concept of hijab in Africa. Such a trend is similar to how Saidat Otiti (Nigeria) organised a hijab themed fashion show, discussed earlier in the introduction. 


\section{Dynamics of Veiling and Muslim Women in Africa}

By the 1900s, African societies were being transformed by Western colonialism. Women used the medium of Western education to teach the Islamic learning they had acquired. Yet, efforts to recognise women in public affairs was shoved aside by reformists. From the period of independence, the symbol and typologies of veiling recurred due to the failure of colonial political and economic systems, causing agitation for veiling to increase. Post-colonial governing systems in Africa saw a period of instability and disruption pointing to the failure of the state, as evident in military coup d'etats. The imbalances created over this period enhanced the veil as a symbolic construct, entrenching Islamic reforms. According to Elodie Apard, transformations in the Muslim world induced paradigm shifts in Islamic revival in Africa. ${ }^{39}$ The logics of mutation and adaptation as manifested from the 1970s created varied forms of identity for women. Invariably, veiling became a tool of power and license to public appearance.

In spite of the challenges, most postcolonial African societies presented the veil as an instrument of negotiation allowing women to participate in public life. ${ }^{40}$ This was profound in Sudan and Northern Nigeria where women used the veil to justify participation in the public sphere over the $1970 \mathrm{~s} .{ }^{41}$ Hence, from the 1970s, the question of veiling in Africa became complicated as it subsumed challenges of legitimacy.

Both Western and Islamic education systems influenced new forms of veiling among educated women. Of course, with the growth of universities in Africa from the 1970s, new forms of Islam that defined veiling for women gradually emerged. This emergence re-organised the fashion of veiling in line with new ideals of Islam as projected by Muslim student groups.

In French West Africa, Kaba analysed how women engaged in Islamic learning and translated it into public engagement. ${ }^{42}$ Individually and collectively, they also blended Islamic learning with Western education, such that they emerged as breadwinners within families. In line with this construct, the veil is central to the politics of identity. It functions in fashion, public identity, political engagement, and spiritual cognisance. This idea of the veil as a symbol of Muslim womanhood is in line with the tradition of the Prophet's wives. ${ }^{43}$ In a study of young Muslim female learners in South Africa, it was discovered that Muslim girls likewise understand the veil as a representation of their identity. ${ }^{44}$

With the intersection of modernisation and fundamentalism, Muslims in contemporary Africa negotiate the use of the veil as a binding force that allows women to live in a modern society without severing their ties with Islamic 
tradition. The phenomenon of veiling in contemporary Africa is essential to the identities, nationalism, and citizenship of its Muslim women.

\section{Conclusion}

This paper teased out how the veil has constructed female Islamic identity throughout African history. It is important to emphasise that the use of veils has varied over time. Before the twentieth century, it signified Islamic consciousness among Muslim women. In contemporary times, veiled Muslim women use the hijab as a symbol of piety and fashion. This is a survival from Ottoman custom. Though the twentieth century debates concerning the history and contemporary relevance of the hijab have shown that Muslim women wear the veil based on their understanding of Islam and not coercion. However, ideological affiliations and affirmations in the political and religious landscape, as well as global influences, have entrenched variations in veiling formats. Since the twentieth century, veiling has featured both resentment and legitimacy. This paper concludes by recommending the following:

- Veiling is a functional component of female Muslim dress in Africa and should be seen as reflective of the long history of Islam.

- Veiling in Africa is a complex tradition that varies across societies and hence reflects the features of migration and settlement. It should be used to aid citizenship and identity management in contemporary governance systems.

- Veiling features as a factor in the making of nationalisms in Africa. It should therefore be a determinant in politics.

- Ultimately, veiling as an object of fashion is a factor in global trade across Asia, the Middle East, and Africa which should boost employment and income generation.

\section{Notes}

* Habibat Oladosu-Uthman, Ph.D, Department of Arabic and Islamic Studies, University of Ibadan, Nigeria. Email: hibbiy@yahoo.com.

** Mutiat Titilope Oladejo, Department of History, University of Ibadan, Nigeria. Email: oladejomutiat@yahoo.com.

1. Elisha Renne, Veiling in Africa (Bloomington: Indiana University Press, 2013), 72 . 
2. Jose C.M. Van Santen, “"My 'veil' Does Not Go With my Jeans": Veiling, Fundamentalism, Education and Women's Agency in Northern Cameroon,' Africa: Journal of the International African 80, no.2 (2010): 275-300.

3. Sahar Amer, What is Veiling (Chapel Hill: The University of North Carolina Press, 2014).

4. Fadwa El Guindi, Veil: Modesty, Privacy and Resistance (Oxford: Berg, 1999).

5. Ayesha M. Imam, 'Politics, Islam and women in Kano, Northern Nigeria,' in Identity Politics and Women: Cultural Assertions and Feminisms in International Perspectives, ed. Valentine M. Moghadan (Boulder, Colo: West view, 1994), 123-44.

6. Huda Lufti, 'Manners and Customs of Fourteenth-Century Cairene Women: Female Anarchy versus Male Shar'i Order in Muslim Prescriptive Treatises,' in Women in Middle Eastern History: Shifting Boundaries in Sex and Gender, ed. Nikki Keddie and Beth Baron (New Haven, Conn.: Yale University Press, 1991), 118-19.

7. Katherine Bullock, Rethinking Muslim Women and Veil, Challenging Historical and Modern Stereotypes (London: The International Institute of Islamic Thought, 2003), xxvii.

8. Ibid.

9. Fatmagül Berktay, 'Looking from the "Other" Side: Is Cultural Relativism a Way Out?' in Women's Studies in the 1990's: Doing Things Differently?, ed. Joanna de Groot and Mary Maynard (London: Macmillan, 1993), 120.

10. Ibid., 123.

11. Ibid.

12. Amina Wadud, Inside the Gender Jihad: Women's Reform in Islam (Oxford: One World, 2006), 158.

13. Fatima Mernissi, Women's Rebellion \& Islamic Memory (London: Zed Books, 1996), 14.

14. Ibid., $94,79$.

15. Asma Barlas, Believing Women in Islam, Unreading Patriarchal Interpretations of the Qur'an (Austin: University of Texas Press, 2004), 86.

16. Afsaneh Najmabadi, 'Feminism in an Islamic Republic, "Years of Hardship, Years of Growth," in Islam, Gender and Social Change, ed. Yvonne Yazbeck Haddad and John L. Esposito (New York, Oxford: Oxford University Press 1998), 59.

17. Haideh Moghissi, Populism and Feminism in Iran: Women's Struggle in a MaleDefined Revolution Movement (Mishawaka: Palgrave Macmillan, 1994), 183.

18. Afsaneh Najmabadi, 'Feminism in an Islamic Republic,' 59-60.

19. Annelies Moors and E. Tarlo, 'Introduction Muslim Fashions,' Fashion Theory 11 no. 2/3 (2007): 133-42.

20. Jean Allman, Fashioning Africa: Power and the Politics of Dress (Bloomington: Indiana University Press, 2004), 3.

21. Catherine Belsey, Critical Practice (New York: Methuen, 1980); Erin Hyde Nolan, 'You Are What You Wear: Ottoman Costume Portraits in the Elbsie-i Osmaniyye,' Ars Orientalis 47 (2017): 4.

22. Wadud, Inside the Gender Jihad.

23. Amer, What is Veiling, 49. 
24. Catherine Belsey, Critical Practice; Nolan, 'You Are What You Wear,' 178-209.

25. Suraiya Faroqhi, Ottoman Cotton Textiles, 1500s to 1800: The Story of Success that Did Not Last (Oxford: Oxford University Press, 2009).

26. Suraiya Faroqhi, Artisans of Empire: Crafts and Crafts people under the Ottomans (New York: I.B. Tauris, 2009).

27. Ibid.

28. Amer, What is Veiling.

29. Ibid., 88 .

30. I.A. Ogunbiyi, 'The Position of Muslim Women as stated by Uthman Dan Fodio Odu,' A Journal of West African Studies 18 no. 2 (1969): 43-60.

31. M.O. Emerson and D. Hartman, 'The Rise of Religious Fundamentalism,' Annual Review of Sociology 32 (2006): 127-44.

32. Asma Barlas, Believing Women in Islam, 12.

33. Ibid., 13.

34. Van Santen, 'My 'Veil' Does Not Go With my Jeans,' 275-300.

35. Oladejo 2017, (JUSREL)

36. R.A. Dunbar 'Muslim Women in African History' in The History of Islam in Africa, ed. Nehemia Levtzion and Randall L. Pouwells (Oxford: James Currey, 2010),

37. Ibid., 405.

38. Hijab Fashion, 2011.

39. Elodie Apard, Transnational Islam: Circulation of Religious Ideas, Actors and Practices Between Niger and Nigeria, West African Politics and Society Series (Leiden: African Studies Centre, 2020).

40. Nehemia Levtzion and Randall L. Pouwells, The History of Islam in Africa (Oxford: James Currey, 2010), 15.

41. Hauwa Mahdi, 'The Hijab in Nigeria, the Woman's Body and the Feminist Private/Public Discourse.' Available at: ascleidenml /news/hijab-nigeria, 2008. (Accessed on: March 3, 2021).

42. L. Kaba, 'Islam in West Africa: Radicalism and the New Ethic of Disagreement, 1900-1960' in The History of Islam in Africa, ed. Nehemia Levtzion and Randall L. Pouwells (Oxford: James Currey, 2010).

43. Levtzion and Pouwells, The History of Islam in Africa, 195.

44. Nafisa Patel, 'Exploring South African Girlhoods: The Self-Identifications of Young Muslim Female learners in Post-apartheid South African High Schools,' Journal for the Study of Religion 26 no. 1 (2013): 61-82.

\section{Bibliography}

Allman, Jean, ed. Fashioning Africa: Power and the Politics of Dress. Bloomington: Indiana University Press, 2004.

Amer, S. What is Veiling. Chapel Hill: The University of North Carolina Press, 2014.

Barlas, Asma. Believing Women in Islam, Unreading Patriarchal Interpretations of the Qur'an. Austin: University of Texas, 2004. 
Belsey, Catherine. Critical Practice. New York: Methuen, 1980.

Berktay, Fatmagül. 'Looking from the "Other" Side: Is Cultural Relativism a Way Out?' In Women's Studies in the 1990's: Doing Things Differently. Edited by Joanna de Groot and Mary Maynard. London: Macmillan, 1993.

Bullock, Katherine. Rethinking Muslim Women and Veil, Challenging Historical and Modern Stereotypes. London: The International Institute of Islamic Thought, 2003.

Dunbar, R. A. 'Muslim Women in African History.' In The History of Islam in Africa. Edited by Levtzion N. and Pouwells, R.L. Oxford: James Currey, 2010.

El Guindi, Fadwa. Veil: Modesty, Privacy and Resistance. Oxford; UK: Berg, 1999.

Elodie Apard, Transnational Islam: Circulation of Religious Ideas, Actors and Practices Between Niger and Nigeria, West African Politics and Society Series. Leiden: African Studies Centre, 2020.

Emerson, M.O. and D. Hartman. 'The Rise of Religious Fundamentalism.' Annual Review of Sociology 32 (2006): 127-144.

Faroqhi, Suraiya. Ottoman Cotton Textiles, 1500s to 1800: The Story of Success that Did Not Last. Oxford: Oxford University Press, 2009.

- Artisans of Empire: Crafts and Crafts people under the Ottomans. New York: I.B. Tauris, 2009.

Imam, Ayesha, M. 'Politics, Islam and Women in Kano, Northern Nigeria.' In Identity Politics and Women: Cultural Assertions and Feminisms in International Perspectives. Edited by Valentine M. Moghadan. Boulder, Colo: West view, 1994.

Kaba, L. 'Islam in West Africa: Radicalism and the New Ethic of disagreement, 1900-1960.' In The History of Islam in Africa. Edited by B. Levtzion N. and Pouwells, R.L. Oxford: James Currey, 2010.

Levtzion, Nehemia and Randall L. Pouwells, The History of Islam in Africa. Oxford: James Currey, 2010.

Lutfi, Huda. 'Manners and Customs of Fourteenth-Century Cairene Women: Female Anarchy versus Male Shar'i Order in Muslim Prescriptive Treatises.' In Women in Middle Eastern History: Shifting Boundaries in Sex and Gender. Edited by Nikki Keddie and Beth Baron. New Haven, Conn.: Yale University Press, 1991.

Mahdi, Hauwa. 'The Hijab in Nigeria, The Woman's Body and the Feminist Private/ Public Discourse.' Available at: ascleidenml /news/hijab-nigeria, 2008.

Mernissi, Fatima. Women's Rebellion \& Islamic Memory. London: Zed Books, 1996.

Moors, Annelies and E. Tarlo. 'Introduction Muslim Fashions.' Fashion Theory 11 no. 2/3 (2007): 133-42.

Najmabadi, Afsaneh. 'Feminism in an Islamic Republic, "Years of Hardship, Years of Growth.' In Islam, Gender, \& Social Change. Edited by Yvonne Yazbeck 
Haddad and John L. Esposito. New York, Oxford: Oxford University Press 1998.

Nolan, Erin Hyde. 'You Are What You Wear: Ottoman Costume Portraits in the Elbsie-i Osmaniyye,' Ars Orientalis 47 (2017): 178-209.

Ogunbiyi, I.A. 'The Position of Muslim Women as Stated by Uthman Dan Fodio.' Odu, A Journal of West African Studies 18 no.2 (1969): 43-60.

Patel, Nafisa. 'Exploring South African Girlhoods: The Self-Identifications of Young Muslim Female learners in Post-apartheid South African High Schools.' Journal for the Study of Religion 26, no. 1 (2013): 61-82.

Renne, Elisha. Veiling in Africa. Bloomington: Indiana University Press, 2013.

Sahar Amer. What is Veiling. Chapel Hill: The University of North Carolina Press, 2014.

Van Santen, Jose C.M. “My 'Veil' Does Not Go With My Jeans": Veiling, Fundamentalism, Education and Women's Agency in Northern Cameroon," Journal of the International African Institute 80 no. 2 (2010): 275-300.

Wadud, Amina. Inside the Gender Jihad: Women's Reform in Islam. Oxford: One World, 2006. 